\title{
二条城二の丸御殿白書院の復原研究
}

建築と障壁画の総合的検討

\section{A STUDY ON THE ORIGINAL PLAN AND THE PANEL PAINTINGS OF THE SHIROSYOIN OF NINOMARU PALACE OF NIJO CASTLE}

\author{
西 和夫*，小沢 朝 江** \\ Kazuo NISHI and Asae OZAWA
}

\begin{abstract}
This is a study on the original plan and the wall paintings of the Shirosyoin of Ninomaru Palace of Nijo Castle. The results are as follows.

1. The Keicho plan of the Shirosyoin can be reconstructed. The alcove and the shelves were originally on the east of the jodannoma. The jodannoma and the Gedannoma were juxtaposed east and west.

2. The length of papers of wall paintings can be classified into the groups of the sliding doors and the walls in all rooms of the Shirosyoin.

3. Analyses of the paper size and the original plan have unveiled the fact that the panel paintings of the Shirosyoin were executed during the kan'ei era.
\end{abstract}

\section{Keywords: Ninomaru Palace of Nijo castle, Shirosyoin, Syoin style, original plan, panel paintings, lengthof papers}

二条城二の丸御殿、白書院、書院造、復原平面、障壁画、料紙寸法

はじめに

二条城二の丸御殿については、川上貢・平井聖両氏を はじめとする多くの研究があり ${ }^{1}$ 、修理工事も行われて いで2)、すでに多くのことか明らかにされている。すな わち、慶長 6 年 (1601) から同 8 年にかけて（以下これ を慶長度造営と呼ぶ) 德川家康によって造営が行われ 寛永 3 年 (1626) の後水尾天皇の行幸に備えて同元年氻 ら3年にかけて（以下これを寛永度造営と呼ぶ）徳川家 光によって、慶長度の御殿の柱などを生かして新築に近 い改築を行ったのか現在の御殿であることか判明し ${ }^{3)} 、$ 障壁画は寛永度造営の際、狩野探幽を中心とする狩野派 絵師たちによって描かれたとされている゙）。

筆者もすでに、慶長度御殿の復原を行い、その成果の 一端を報告した ${ }^{5)}$ 。

ここでは、その後判明したことと合わせ、二の丸御殿 のうち白書院について、建築と障壁画の総合的検討をも とに、慶長度造営の平面等について報告する ${ }^{6)}$ 。

\section{1. 建築の検討}

1-1 痕跡による検討

現在の白畫院の天井長押や内法長押には、かつてそこ に柱または束があったことを示す埋木や釘跡か諸所にあ り、復原検討上の資料となる。たとえば、図 3 のA・B の位置にはかってそこに柱が立っていたことを示す痕跡 があり、しかもその真上に位置する梁の下端には柱上端 の柄が入る柄究があって、ここに柱が立っていたことを 裏付ける。また床下には、それと対応する位置に現在使 われていない礎石残っている（図 4・6）。以上の諸 点から、かってここに柱が立っていたことか明らかとな る。復原された柱配置は床と違棚の存在を示し、現在上 段の間北側にある床と違棚が西側にあったことになる。

帳台の間・四の間の 2 室は現在、間仕切壁で仕切られ ている。間仕切壁北端は柱ではなく半柱（図3のE、図 9）で引違建具の途中に位置し、この建具は東半分か四 の間に、西半分か帳台の間に面する中途半端な状態にな っている。また、間仕切壁の 4 本の柱（うち2 本は半柱）

\footnotetext{
* 神奈川大学工学部建築学科 教授 $\cdot$ 工博

** 湘北短期大学生活科学科 専任講師 - 工修
} Prof., Dept. of Architecture, Faculty of Engineering, Kanagawa University, Dr. Eng. Lecturer, Dept. of Living Science, Shohoku College, M. Eng. 
はいずれも礎石に達しておらず、大引上に立っている。 2本の半柱は天井より上には延びず、残る 2 本の柱上部 は梁まで達せず紻い材で梁と媇ぐだけで、4本とも後か ら入れたことが明らかである。2室の格天井は、間仕切 壁の真上の位置で格縁を 1 本抜いて2つに分けただけで

（図 1）、当初は 3 間 $\times 3$ 間の天井だったことが明らか である。以上の諸点から、当初は帳台の間と四の間を区 切る間仕切壁がなく、3間 $\times 3$ 間の 1 室であったことが 半明する。

上段の間と帳台の間の境に立つ柱（図 3 のC・D）に は上段框の痕跡があり（図 7・8）、この柱は位置を替 えていないと判断されるため、かつてここが上段・下段 の境で、現在の上段の間が当初も上段の間、現在の帳台 の間・四の間 ( 3 間 $\times 3$ 間の 1 室) が下段の間だったこ とになる。

また、上段の間の格天井には、西側に「北かわ西より 二」、北側に「東かわ南より三」などの墨書があり、方 位力現在と90度ずれている。 2 間半 $\times 3$ 間の現在の格天 井は、復原される上段の間の天井と同じ大きさで、この 墨書の方位と合わせて考えれば、当初の天井を 90 度回転 して用いたと判断される。

このように、白書院は現状とは異なる平面に復原され

る(詳紐は後述) が、寛永行幸時の指図 ${ }^{7)}$ ではすでに現 状の平面となっており、復原平面は寛永度造営より遡る ことになる。すでに明らかにされている通り、二の丸御 殿は慶長度造営建物を寛永度造営て改造したものである ${ }^{8)}$ から、復原される平面は慶長度のものと考えるのか浽当 である゙ 。

\section{1-2 造営文書による検討}

二条城の慶長度造営文書の中の、年紀も表題もない材 木帳 ${ }^{10}$ (以下、『材木帳』之呼ぶ）は、すでに川上貢氏 によって慶長度の二条城のうち奥向の建物のものである ことか明らかにされている11。また、すでに指摘され ているように、慶長度の二条城には、表から順に「広間」 （南殿とも呼ぶ）、晝院」(前殿とも呼ぶ)、「奥御座間」 (奥ノ間とも呼ぶ) と呼ばれる建物加存在した ${ }^{12)}$ 。こ のうち、奥向きに用いられた「奥御座間」が白害院に該 当するとされ ${ }^{13)} 、$ 狺経卿記』によれば慶長 8 年 4 月 1 日に家康と秀忠の対面に用いられているから、遅くとも このときには存在している。また、『材木帳』の小屋材 の寸法や本数は白書院の現状に合致し14)、また柱など の化粧材も復原平面に合致する ${ }^{15)}$ 。したがって、この

『材木帳』は白書院の慶長度造営のものと考えられる ${ }^{16)} 。$

『材木帳』には、「おなんとかまえのしきいかもい (御納戸構の敷居、鴨居)、「おなんとの玉小ち」(御納 戸の玉縁) をはじめ、「よせしきい(寄敨居)、「戸のさ んかまち」(栈框)、「付柱しょうき」(定規)に使う材があ
り、慶長度の白書院に納戸構があったことを示している。 また、『材木帳』に「とこかまち」とあり、慶長度に床 框をもつ床があった。この床框や、たたなのとこ板」棚 の床板）、「たな板」の寸法は現在のものと一致し ${ }^{17}$ 、寛 永度に改造する際、慶長度の床框と棚板を用いたと考え られる。『材木帳』には付書院に関する記事がなく、ま た寛永度の材木帳 ${ }^{182}$ に白書院の付書院の棚板に相当す る材が含まれているから、付書院は寛永度に新たに作ら れた可能性が高い。

このほか、『材木帳』により 3 間長さの鴨居・敷居 2 ヶ所、 1 間長さの鴨居・敷居 3 ヶ所、遣戸 12 所などの 存在が明らかとなり、建具の様相も判明する。

\section{$1-3$ 慶長度平面の復原}

以上を総合すると、白畫院は図 5 のように復原される。 現在北側にある床と違棚は西側に位置し、床が右（北㑡）、 違棚が左（南側）となる。現在の上段の間と帳台の間の 境に上段框が入り、現在の上段の間が慶長度にも上段の 間、現在の帳台の間・四の間か下段の間となって、上段 ・下段 2 室が東西方向に並ぶ平面となる。床を右、違棚 を左に置く形式は、慶長10年(1605)の観智院客殿などの 現存例や、寛永20年(1643)の江戸城二の丸大奥対面所 ${ }^{19}$ や同二の丸表能舞台北の御殿201など文献上の例がある。 この能舞台北の御殿の場合、床の右手に「御泉水」があ

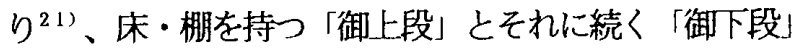
はこの「御泉水」を見るための構成と考えられる。慶長 度の白書院も北または北東に庭があった可能性が高く ${ }^{22}$ 、 それを見るための構成ではないかと思われる。

帳台構は、先に述べた通り、『材木帳』によってその存 在か判明する。すでに、床・棚（上段の間西側）と上段 框 (同東側) の位置が決まったので、帳台構の位置は上

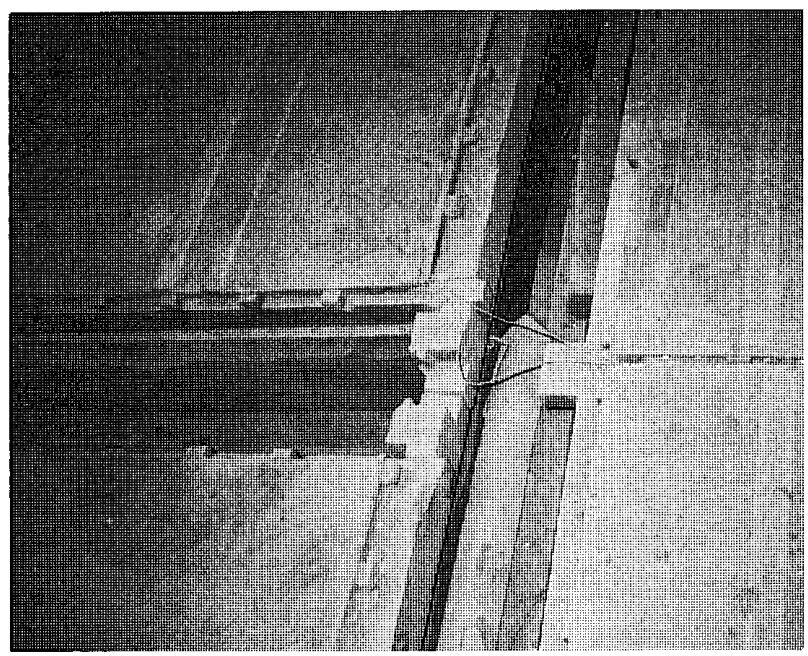

図 1 四の間・帳台の間の境で格縁を1本 拔いている状况 （右側は三の間、 左奥が四の間、左手前が帳台の間) 


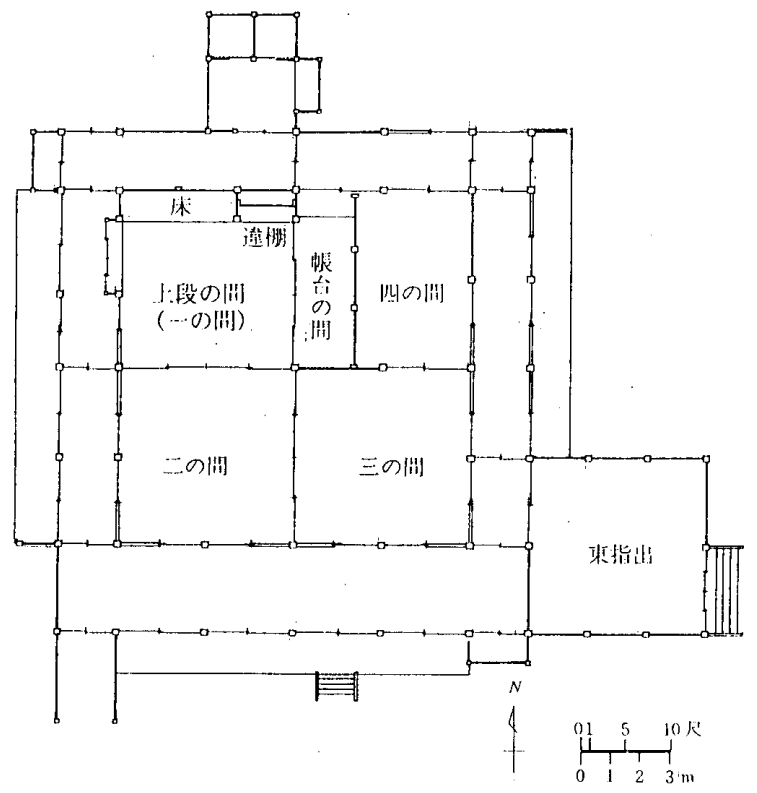

図 2 現状平面図

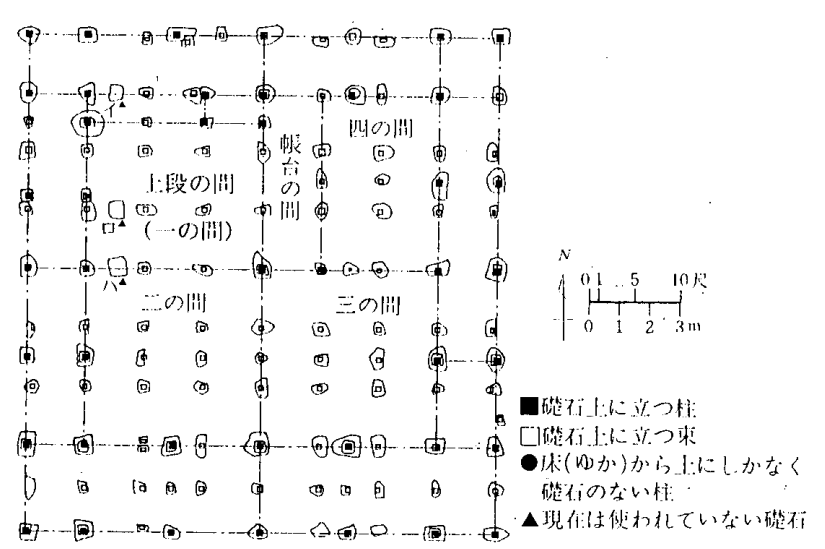

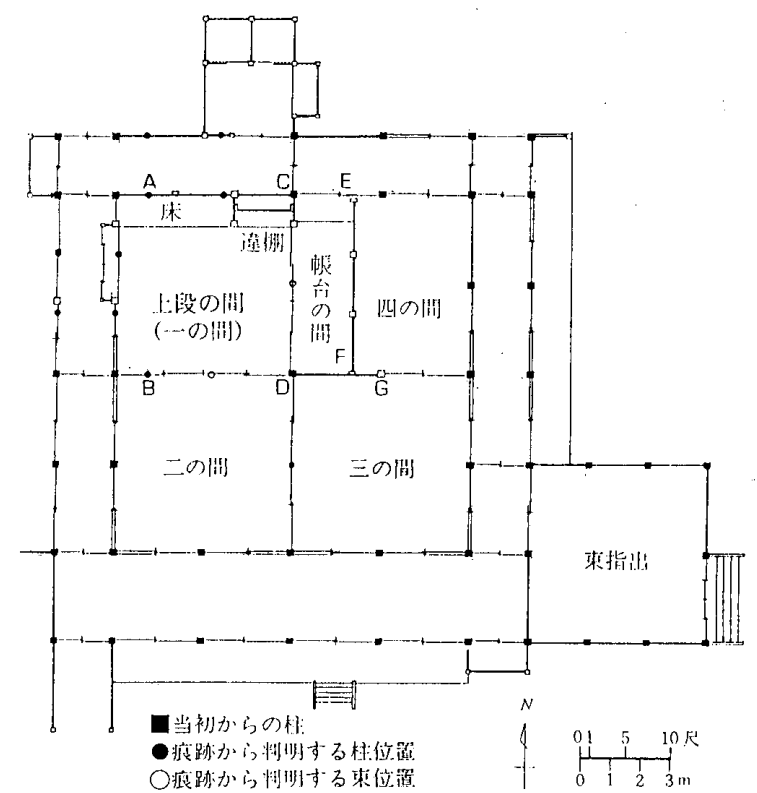

図 3 痕跡図

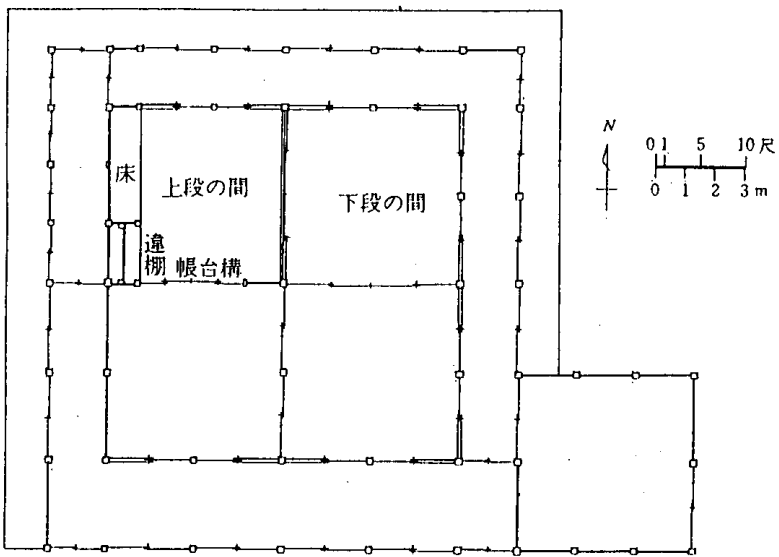

図 5 復原平面図

東指出は壁が多く、痕跡が調査できないため、現状のま

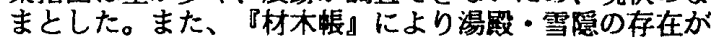
わかるが、不明なため復原図には記人していない。

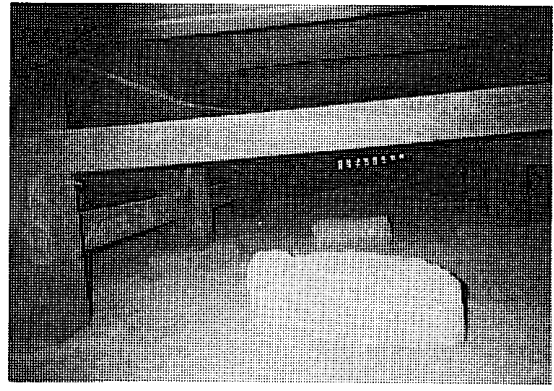

図 6 床下に残る現在使われていない礎石 （南から見る。手前が図 4 のハ、奥がロ）

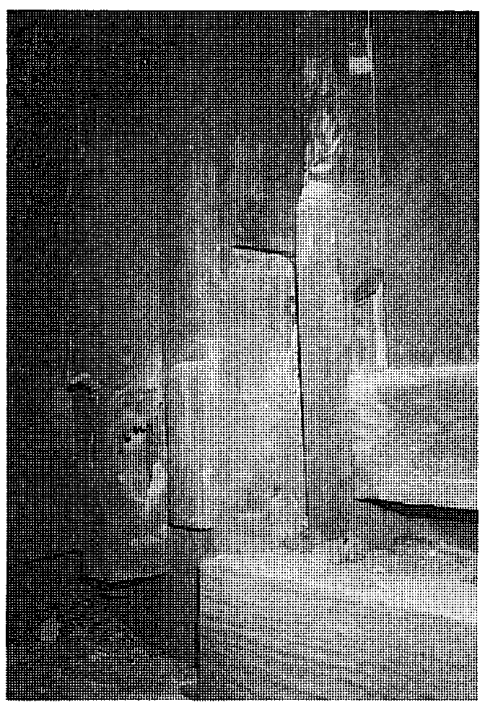

図 7 上段框の痕跡(図 30 C柱)

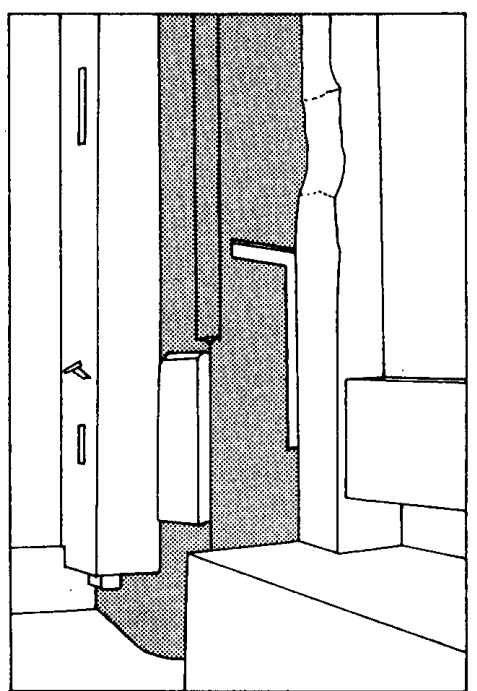

図 8 同 説明図

アミかけがC柱、その中の白く抜い た鍵形が、段框の痕跡。 
段の間北側または南側となる。しかし、上段の間北側に は痕跡により内法長押か廻っていたことか判明し、『材 木帳』による建具の紛数からそこに建具が入ることもわ かるため、慶長度の帳台構は上段の間南側にあったこと になる ${ }^{23)}$ 。

\section{2. 障壁画の検討}

\section{$2-1$ 料䉻寸法による検討}

二条城二の丸御殿の障壁画は、先行研究によって寛永 度造営に際して描かれたとされている(4)。しかしその 根努柱に、天明頃のものとされる ${ }^{25)}$ 『二條御城御指 図』 26) で、他に史料を欠くため造営から1世紀半も後 のこの史料に頼らざるをえない実情にあるが、本当に寛 永度のものか、他の根拠により確認する必要がある。そ の確認は、障壁画自体の検討によって行うことが望まし いが、障壁画そのものによって寛永度であることを直接、 そして明確に示すのは困難である。

障壁画自体の検討はもちろん今迄も行われている。い わゆる様式論によるその検討は状况証拠としては有効だ が、直接的証拠とするのは難しい。そこで本研究では、 障壁画そのものによって検討する一方法として、料紙の 寸法を実測し、その分析を建築の復原考察と総合させる 方法を採ることにした。建具あるいは貼付壁の障壁画は、 数枚の料紙を継ぎ合わせて画面としている。1 枚の料紙 の縦の寸法について、表面に見えている寸法と重称合わ せの寸法（糊代といってもよい）を実測し、綐軸に表面 に見えている寸法、横軸に実寸法 (表面に見えている寸 法と重ね合わせの寸法の合計）をとってグラフを作成し 検討する。料紙寸法自体は一見無朱乾燥な数値に過ぎな いが、の方法が建築と障壁画を検討する上に有効なこ とは、大仙院本堂・園城寺勧学院客殿 - 同光浄院客殿 名古屋城本丸御殿などをもとにすでに報告した ${ }^{27) 。}$

白晝院の料紙寸法は図12のグラフの通りで、5室の障 壁画は部屋毎に図様が異なるにもかかわらず、料紙寸法 は部屋毎に異ならず、5 室共通して、建具グループと貼 付グループに分かれ ${ }^{28)}$ 、さらに貼付グループは内法長 押の上と下とに分かれるという特性を持つ ${ }^{29)}$ 。言(換 えれば、料紙は、建具は 5 室ともひとつのグループ、内 法長押下の貼付も 5 室ともひとつのグループ、内法長押 上の貼付も 5 室ともひとつのグループである。

\section{$2-2$ 建築との総合的検討}

白書院は、先に述べた通り慶長度と判断される平面が 復原され、現在の帳台の間と四の間は寛永度の改築の結 果であることか判明したが、このことと障壁画料紙寸法 の特性とを総合させると、障壁画が寛永度のものである ことが以下に述べるように明確になる。

帳台の間の北側は幅 1 間だが、そこに入る建具（舞良
戸、内側は貼付）は1間半幅に2本（弓違）となってい る。このため内側から見て右側の建具は、1枚の建具の 部 (内側から見て左側) が帳台の間に面し、残る部分 (同じく右側) が四の間に面しており、その建具の内㑡 の絵は、一部は帳台の間の図様、残る部分は四の間の図 様となっている（図10・11）。ふたつの図様の境界に継 に線を引いて左と右に分け、左側に帳台の間の図様であ る草花、右側に四の間の図様である雪景色の樹木を描い ている。境界線を引いたところは紙の継ぎ目ではなく、 紙は線の左右で連続している。左右の異なる絵は、別々 に描いて張り込んだのではなく、描き分けたのである。

1 枚の建具の絵を描き分けたのは、言うまでもなくこ こに間仕切があるからである。その間仕切壁は、すでに 述べた通り慶長度には存在せず、寛永度に設置された。 北側の建具を慶長度のままの構成（絵を除く）としたた め、中途半端な状况となった。したがって境界線で左右 を描き分けた絵は、慶長度ではなく寬永度となる。また、 間仕切壁两面の絵は、間仕切壁そのものか慶長度には存 在しなかったのだから、寛永度のものとなる。さらに、 これと図様が連続する帳台の間と四の間内側の残りの絵 も、いずれも寛永度のものとなる。

先に述べたように、白書院の障壁画はこの帳台の間・ 四の間も含めすべて料紙寸法の特性が同じで、二条城以 外の多くの調查結果 ${ }^{301}$ からみて同一時期に描かれたと 判断するのが妥当である。すなわち、白亩院の障壁画は すべて寛永度のものとなる。1世紀半も降る文献史料に よってではなく、障壁画自体から直接、しかも明確に寛 永度のものと初めて判明した。

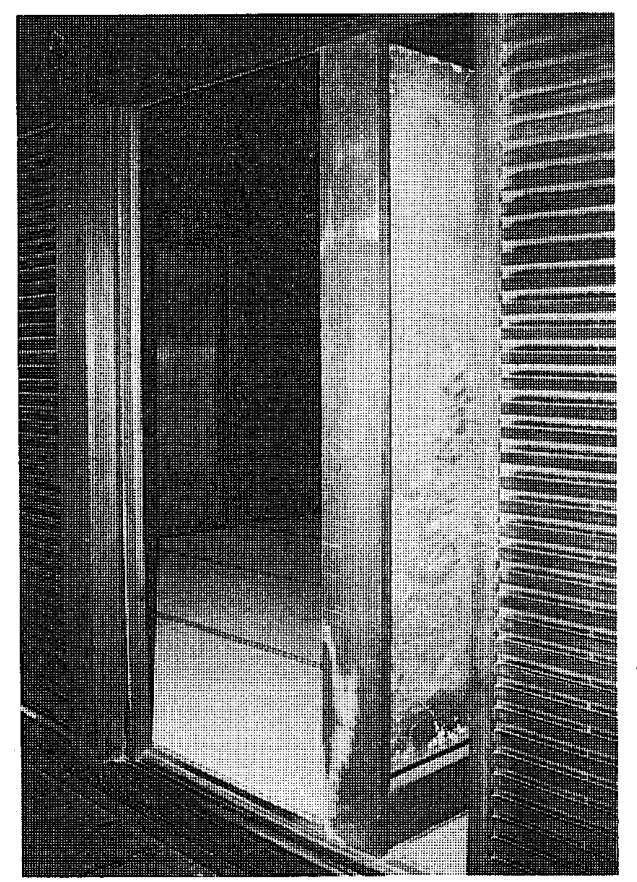

図 9 四の間・帳台の間間仕切壁北端 （北入側から見る） 


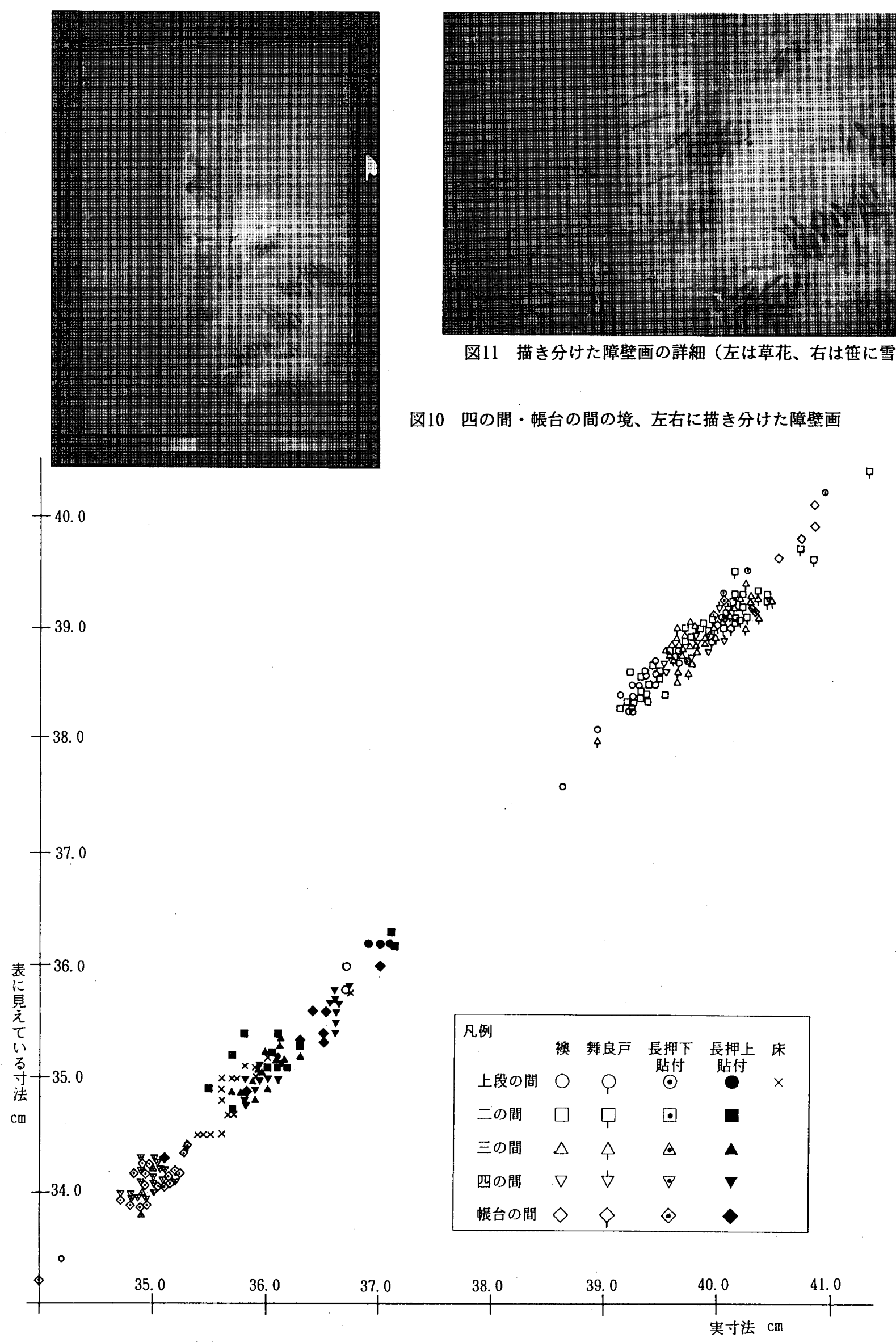

図12障壁画の料紙寸法 
おわりに

以上、二条城二の丸御殿白書院について、建築と障壁 画の両面から検討を行い、慶長度平面の復原等を行った。 判明した主な点は次の通りである。

(1)白書院は、痕跡及び造営文書により慶長度の平面を復 原することができる。現在上段の間北側にある床・棚 は西側にあり、床が右、違棚が左となる。付畫院はな く、帳台構は床・棚の左手（南側）に位置する。現在 の上段の間か慶長度にも上段の間、現在の帳台の間・ 四の間か下段の間で、上段の間と下段の間が東西に並 ふ溝成であった。

(2)白書院の障壁画の料紙寸法は、5室とも共通して、建 具グループと貼付グループに分かれ さらに貼付グル 一プは内法長押の上と下とに分かれる。

(3)白書院の復原平面と料紙寸法の検討結果を総合させる と、白畫院の障壁画はすべて寛永度のものであること か判明する。

以上の諸点は、建築と障壁画を総合させた検討から得 られたものであり、この方法の有効性を明確に示してい る。なお、二条城二の丸御殿大広間の検討も進めており、 稿を改めて報告する予定である。

(註)

1）澤島英太郎・吉永義信『二條城』相模書房・1942年、「二 条城の創建及び沿革に関する考察」『重要文化財二条城 修理工事報告書第三集』恩賜元離宮二条城事務所・1958 年、川上貢「二条城の規模と建筑の変遷」『元離宮二條 城』小学館・1974年、平并聖・斎藤英伐「二条城二の丸 御殿大広間・黑書院」『日本建築史基䃈資料集成十七 書院 II』中央公論美術出版・1974年、西和夫「二条城の 建筑史一造営実態の探究」『名宝日本の美術 姫路城 と二條娍』小学館・1981年・改定版1991年、など。

2）『重要文化財二条城修理工事報告書第 1 集 5 集』恩賜 元離宮二条城事務所・1955 76年。

3）註 1 の報告書および川上・平井論文。

4）土居次義「障壁画 二之丸御殿遠侍・白書院」註 1 『元 離宮二條城』、武田恒夫「障壁画 二之丸御殿大広間・ 式台・黑書院」註 1 『元離宮二條城』、山根有三「队满 院の障壁画」『全集日本の古寺第六巻』集英社・1985年 松木寛『御用絵印狩野派の血と力』講談社・1994年、な ど。

5）註 1 西和夫 「二条城の建筑史」、西和夫「二条城二之丸 御殿大広間の慶長創建時の平面について」日本建築学会 大会学術講演梗概集・1980年、西和夫 - 小沢朝江「二条 城二の丸御殿の研究 一建勧平面之障壁画の復原 (上)

（下）」國華第1068・1071号・1993年 3 月 - 6 月、西和夫 ・小沢朝江・天木詠子「二条城二の丸御殿における建築
と障壁画の総合的検討 一白畫院・大広間の慶長度平面 の復原を中心に」日本建勧学会大会学術譐演梗概集 $\cdot 19$ 93年 9 月、小沢朝江「将軍の居間・白書院復原」『名城 シリース 二条城』学研・1996年。

6）本報告は、註 5 の既発表諭文をさらに前進させたもので あって、新たに判明した諸点を加えて執筆している。

7) 『二條御城中絵図』（中井家蔵）、寞永行幸御城内図』 (宮内庁書陵部蔵)など。

8）註 3 に同じ。

9) 二条城は、慶長度と筧永度の間に、元和 5 年 (1617) か ら同 6 年にかけて、徳川秀忠息女和子の入内に備えて造 営が行われており (以下、元和度と呼ぶ)、元和度造営 の可能性も考え执はならぬが、元和度造営の建物は伏見 城からの移筑で、しかも規模が白書院とは合致せず（註 $1 川$ 上論文)、元和度造営の可能性は否定される。

10）京都府立棇合資料館葴。冒頭之末尾が欠けていると考え られ、どの建物のものか不明であった。

11) 註 1 川上論文。

12）註11に同じ。

13）註11に同じ。

14）冒頭と末尾が欠けているため、本数の比較は困難だが、 例えばにこや桁」（母屋および棟木に相当）は、『材木 帳』では 5 寸角・長さ 2 間・53本、現状は 4 寸 6 分角・ 長さ 2 間・53本（身舎が母屋列 9 通りで 48 本、東指出が 母屋列 4 通りで 5 本、計 53 本) で、太さは仕上げのため やや減じていると考えられるので、寸法・本数とも合致 する。同様に、「さん引物」（梁に相当）は『材木帳』 では末口 1 尺・長さ 3 間 1 尺・13本、現状では末口 9 寸 -長さ 3 間 1 尺・ 13 本（身舎10本、東指出 3 本、計13本） で合致し、また「急ん析」幅 1 尺 7 寸・厚さ 8 寸（現状 は成 1 尺 6 寸 8 分・幅 8 寸) や「出引 1 尺角・長さ 3 間 1 尺（敖析に相当。現状は 9 寸角・長さ 3 間 1 尺）な どの材の寸法も合致する。

15）柱は、『材木帳』では7 7角・長さ 2 間 2 尺の「柱」が 52 本、6 寸 5 分角・長さ 2 間の「とこ柱」が 3 本、6 寸 5 分角・長さ 2 間の「たな柱、同だいわ」が 2 本（いず れも檜）の計57本で、一方、復原では東指出を含めると 6 寸 3 分角の柱（床柱を含む）が54本、半柱が 3 本の計 57本で、半柱を含めれば本数は合致する。ただし、太さ は仕上げのためやや減じていると考えられる。同粎に、 床框 (『材木帳』は幅 5 寸・厚さ 4 寸・長さ 2 間、現状 (本文で述べるうに、慶長度の材を転用) は幅 4 寸 8 分・厚さ 3 寸 2 分・長さ 2 間) や「たなのとこ板」( 啉 木帳』は幅 1 尺 6 寸・厚さ 4 寸・長さ 1 間、現状 (同じ 〈慶長度の材を転用〉は幅 1 尺 5 寸 5 分・厚さ 3 寸 4 分 ・長さ 1 間) 等の寸法も合致する。

16）註 1 論文で川上貢氏は、『材木帳』の棟束の本数が10本 で、1 1 問間隔で立つとすると析行間数は 9 間以上である 
ため、この『材木帳』は白書院より大きく、黒書院よ り小さい程度の御殿建物」のものであるとされた。しか し、この棟束をはじめ柱などの本数は、東指出を含めれ ばよく合致する。『材木帳』に書き上げられた「ひち木」 （时木）は現在白書院の東指出部分にしかなく、東指出 は慶長度にも存在したと考えられ、『材木艮』はこの東 指出を含めた慶長度白書院のものと判断される。

17）註15の床框と「たなのとこ板」参照。

18）『二條御城御作事御材木高払帐』京都府立総合資料館蔵。

19）『二丸御絵図』内閣文庫蔵。

20)部19に同じ。

21) 芸19に同じ。

22）『駿俯記』によれば、慶長20年 7 月17日、家康は「前殿」 （黒書院に相当、註 1 川上論文）での対面ののち、「泉 水御座数」に伝奏を召して指示を与えており、奥向の建 物のいずれかの部屋が庭園に面していたことが窺われる。 罂長度の白書院の周囲に「泉水」が存在したとすると、 西側には床・違棚があり、東南には東指出があり、南側 には後に述べるように帳台の間があるため、「泉水」は 北または北東にあった可能性が高い。

23）『材木帴』は納戸構の敖居・鴨居の長さを 2 間としてお り、度長度の上段の間南側の、棚の奥行を除いた 2 間半 と合致しない。また現在の上段の間南東隅柱西面には壁 などの痕跡は見られず、帳台構左右の様相は不明だが、 これ以外の史料を欠くため、ここでは 2 間幅の帳台棈を 西に寄せた状態で復原しておく。なお、白書院四の間の 柱（図 3 のE・G）は、多数の埋木を持つことなどから 転用材であることが明らかだが、帳台構と判断される痕 跡があり、㦄長度には帳台構雨端に位犆していた可能性 がある。

24) 註 4 の諸論文。

25）『二條御城御指図』は、本丸部分には本丸御殿の平面を 描いた上に全酒に貼紙をし、また二の丸部分には付篓で 各部屋の画題と御殿毎の障壁画筆者を記している。本丸 の貼紙は本丸が焼失した天明 8 年 (1788) から程遠から ぬ頃のものとされ、二の丸の付笼も同時期のものと考え られる。註 4 武田論文。

26）宮内庁書陵部蔵。

27）西和夫「大仙院本堂障壁画の料紙寸法による検討」日本 建築学会関東支部研究報告・1993年、西和夫・小沢朝江 -天木詠子「園城寺勧学院客殿・光浄院客殿の障壁画の 料紙寸法による検討」日本建築学会関東支部研究報告・ 1993年、西和夫「名古屋城本丸御殿とその障壁画につい て一料紙寸法による総合的検討」日本建築学会大会学 術講演梗概集・1993年、など。

28）貼付グループ中の床（とこ）は、一部内法長押の上グル 一プに含まれつつ、長押の上と下との中間に分布する。 建具グループは、舞良戸内側の寸法がやや大きく、襖が
やや小さい傾向を見せるが、明確に分かれてはいない。 29）二の㚘御殿の白書院以外の料紙寸法は(1)大広間 - 式台 • 遠侍は、貼付も建具も、内法長押の上も下もすべて同じ 寸法で、床（とこ）だけは大きい、(2)黑書院は、内法長 押の上と下との差はなく、建具と貼付で寸法が異なる。 白書院も含めて、これらの特性から二の丸御殿は(a)大広 間・式台・遠侍(b)黒畫院(c)白書院の 3 グループに分けら れ、このグループ分けは寛永度の 3 人の造営奉行の担当 の別と一致する。以上の諸点をすでに註 5 の國華諭文で 報告した。ただし、その後の検討により、すでに一部見 解が異なっており、今回の報告が修正を加えた最新のも のである。

30）註27に同じ。

なお、障壁画の検討については、美術史の大手前女子大学 教授武田恒夫・学習院大学教授千野香織両氏のこ教示を得た。 また、調査に当たっては、元離宮二条城事務所の宇野幸次・ 高橋修二・坂井清の諸氏にお世話になった。記して感謝した い。

（1996年 4 月 10 日原稿受理，1996年 6 月 20 日採用決定） 